IKONOMIKA: Jurnal Ekonomi dan Bisnis Islam

Volume 3, No. 2 (2018.)

ISSN : 2527-3434 (PRINT) - ISSN: 2527-5I43 (ONLINE)

Page : I89- 204

\title{
Mobilisation of Income Zakat Payment In Indonesia
}

\author{
Caturida Meiwanto Doktoralina ${ }^{\mathrm{I}}$, Zakaria Bahari ${ }^{2}$, \\ Sakinatul Raadiyah Abdullah ${ }^{3}$ \\ Universitas Mercu Buana ${ }^{1}$,Universiti Sains Malaysia ${ }^{2,3}$ \\ caturida_meiwanto_drm@mercubuana.ac.id,bzak@,usm.my², \\ sakinatu15667@,yahoo.com ${ }^{3}$
}

\begin{abstract}
The objectives of the study establish a conceptual framework to strengthen institutions that support the mobilisation of paying zakat and to identify the concept of the cultural factor of mutual assistance in paying zakat. This is Important because the institution of zakat has implemented the collection of zakat. Meanwhile, the culture of mutual assistance in Indonesia can be a power of zakat payment mobilisation to gain the blessings of Allah SWT. This paper presents the factors of determining mobilisation of zakat payments, e.g., are awareness, willingness to donate, confidence in collection and distribution with the latest development of technology. The implication of this study will help mobilise the payment of income zakat in Zakat Institutions. This study uses the documentation analysis method. Factors affecting mobilisation are awareness, willingness to donate, confidence in collection and distribution with the latest development of technology to help mobilise the payment of income zakat in Zakat Institutions.
\end{abstract}

Keywords : Collection, Mobilisation, Payment, Sincerity, Zakat

\section{A. . INTRODUCTION}

Islam is a religion based on the revelation of Allah SWT of the Quran, al-Hadith and sharia that guide human behaviours. One of the mandatory practices is related to the payment of income zakat. The payment of zakat according to Islam is actually stated in the Qur'an in Surah al-Baqarah (2: 267) and Hadith Bukhari, (No. Hadith 7I9 \& 749) and Hadith Muslim, (No. Hadith 940 \& 94I). In fact, zakat is mentioned in the Qur'an as many as 30 times and as many as 27 times the zakat mentioned along with the practice of prayer (Hj. Abdul Majid, 2003:8). In Islamic sharia, zakat practice can purify the soul and purify property(Hussain \& Abdullah, 20I5)and is a mandatory practice for financially secured people and has fulfiled the needs of nisab and haul(Arafah \& Nugroho, 2016; Nugroho \& Husnadi, 2017; Powell, 2009).

Zakat has four major socio-economic objectives namely reducing poverty and maintaining socio-economic justice (Al Haq \& Abd. Wahab, 2017; Bidin, Idris, Shamsudin, \& Faridahwati, 2009; Bremer, 2013; Hassan \& Ashraf, 2010; Hati \& Idris, 20I4; Khamis, Mohd, Md Salleh, \& Nawi, 20I4; Muliyaningsih, 20I3) nurturing people from envy, cleansing the wealth of zakat payers and eliminating fraud and educating Muslims into philanthropy, peace and prosperity

Received : January I4, 2018 - Revised: January I4, 2018 - Accepted :January I5, 2018

Universitas Mercu Buana ${ }^{1}$,Universiti Sains Malaysia ${ }^{2,3}$

E-Mail: caturida meiwanto drm@,mercubuana.ac.id, bzak@usm.my²,

sakinatu15667@,yahoo.com ${ }^{3}$ 
(Abdullah \& Suhaib, 20I I; Yusuf Al Qardawi, 20II). This explains that zakat is an intermediary of the faith of the blessings of Allah SWT and that this practice is not a burden, but it is the responsibility of the Muslim individuals towards its revenue (Doktoralina, 2017; Doktoralina \& Bahari, 2017).

The potential of world zakat reaches USD 600 million (Beik, 20I5). In the Member States of the Organization of the Islamic Conference (OIC), the potential of zakat is between I.8-4.3\% of the total of state revenue (Kahf, 2008). Indonesia, as the world's largest Muslim population, 230 million people (87.2\%) from 262 million people (Desilver \& Masci, 20I7; Lessy, 2009; Sari, Bahari, \& Hamat, 2013) has a low zakat collection. The zakat collection in Indonesia is I.3\% of the expected potential (Badan Amil Zakat Nasional, 20I8). Seeing this fact, the practice of zakat is not implemented as commanded by Islam. Therefore, zakat institutions need to raise cultures of mutual assistance in Indonesia to obtain real data, methods or indices on poverty (Haughton \& Khandker, 2009; Khandker, Koolwal, \& Samad, 2009).

Indonesian nationality slogan, Bhineka Tunggal Ika (Unity in Diversity) which is a reference to the diverse religious, cultural and ethnic traditions (Osili \& Ökten, 20I6) must be re-encouraged. The mutual assistance in doing this virtue and taqwa has been described in the Qur'an as in surah al-Taubah (9:7I) and al-Ma'idah (5:2). Therefore, zakat mobilisation in Indonesia is needed by optimising the role of the community and paying attention to zakat institutions. Collection and management of zakat must imply Islamic financial development (Muhammad Abdullah \& Abdul Quddus Suhaib, 20II). However, some Islamic countries that have implemented zakat management are not fully applied in Indonesia due to ideological and cultural issues in Indonesia (Wibisono, 2015).

In recent decades, the mobilisation approach of paying zakat is still traditional, such as sending amil to every home (Salleh, 2006). Today, as many as I22 million Indonesians are actively involved in using technology equipment as a convenience (Ministry of Communication and Informatics, 2017). About II2 million people are categorised as obligatory zakat(Badan Amil Zakat Nasional, 2018). Therefore, we need a new strategy for optimising the collection of income zakat. It will also provide the convenience of earning zakat income from diversified activity sources (Abu Bakar \& Abdul Rashid, 2010; Bidin et al., 2009; Doktoralina, 2017; Doktoralina \& Bahari, 20I7; Khamis et al., 20I4; Syahrullah \& Ulfah, 20I6; Waddell, 2000).

Muslim refusal to pay income zakat in Indonesia is caused by motivation factor (Doktoralina, 2016a, 20I6b; Doktoralina \& Bahari, 2017). Even individuals who pay zakat are more middle-income groups than the high-income groups (Kasri, 2013). Therefore, spiritual and material aspects can be improved (Mohd Noor, Wahid, \& Nor Ghani Md., 2004) to build mobilisation of real Islamic economics with mardhatillah(Salleh, 20I8). The trick is to optimise the role of society in the right direction in paying zakat (Abdullah \& Suhaib, 20I I). This needs to be done by taking into account the success of Islamic history development in Indonesia to tailor local cultural approaches, and the government supports the mobilisation of zakat payments through the regulation with the aim of zakat institutions and government agencies to achieve the goals (Halimatusa'diyah, 2015).

The mobilisation of paying zakat needs to be efficiently managed (Siswantoro \& Nurhayati, 2012). Distribution of zakat to eight groups of asnaf(Johari, Mohd Ali, Aziz, \& Ahmad, 20I4) also must be publicly disclosed. Cultural aspects should also be considered as 
approaches. This is because of many cultures, tribes and folks in Indonesia (Yunianto et al., 2017).

Based on this study is essential because the mobilisation of paying zakat is less attractive to Muslims than the aspect of income zakat. The question is, whether the cultural factors of mutual assistance between the people of Indonesia can strengthen cooperation between zakat institutions? Is the implementation of specific rules can enhance the application of zakat payment? This paper has two main parts: first, establishing a conceptual framework to strengthen government institutions that support the mobilisation of paying zakat, secondly, identifying the concept of the cultural factor of mutual help in paying zakat.

\section{B. THEORITICAL}

This literature review covers studies that relate to previous literature studies that have relevance. This literary study discusses Zakat Management (collection, administration and distribution of zakat), payment and distribution of income zakat in Indonesia, mobilisation and mutual assistance culture in the payment of zakat.

Zakat management in Indonesia (such as collection, management, distribution) is done by zakat and private institutions (Ministry of Religious Affairs of the Republic of Indonesia, 2018). It's listed in Government Regulation of the Republic of Indonesia Number I4 on the implementation of law No. 23 of 2014 on zakat management. However, there are still things that must be reinforced that are about the synergy of zakat potential obtained from muzakki and the validity of mustahiqq data. This is important because the zakat potential against the reality is low. Therefore, there have been many studies to find the solution (Huda, Anggraini, Muhamad Ali, Rini, \& Mardoni, 20I4).

Some studies on zakat management indicate a lack of coordination between zakat institutions (Jahar, 2010; Sari et al., 2013). Mainly is an activity program such as zakat as a tax deduction (Abu Bakar \& Abdul Rahman, 2007; Andriani \& Fathya, 2013; Badan Amil Zakat Nasional, 2018; Kahf, 1999) and the mechanisms of activity reporting (Doktoralina \& Bahari, 2018; Raquib, 20II), transparency (Suryanto, 20I4; Wahid, Ahmad, \& Kader, 2009) Thus, zakat management in Indonesia must separate clearly the roles of between government and zakat institutions. The government acts as a regulator and supervisor. While the zakat institution strengthens its position in the rise and prosperity of the Ummah(Sudarwati \& Sayekti, 20II). It is important that maintenance efficiency is implemented. The trick is to educate the public about the importance of zakat, to strengthen trustworthiness and professionalism of the amil zakat, to align the distribution program and to manage institutions transparently (Hafidhuddin, 20II) with the support of government regulation (Beik \& Arsyianti, 20I3).

Regarding Payment (collection) and Distribution of income zakat in Indonesia, Islam teaches about income earning in a good way as stated in the Quran in surah al-Mu'minun (23:5I), surah. al-Baqarah (2: I88) and Hadith History of Imam ad-Dailami, (No.hadith 5270) and Hadith History of Imam as-Suyuti, (Hadith 5273). Generally, the concept of livelihoods as a base of value added to activities that follow religious guidelines for human welfare (maslahat) has become a discussion (Mulawarman, 2009; Nastiti \& Wardayati, 2015). This means income needs to be subject to zakat (Abu Bakar \& Abdul Rashid, 20I0) instead of putting accommodative modifications into the Western ethnocentric concept (Salleh, 20I4). This is a

https:/ / ejournal.radenintan.ac.id/index.php/ikonomika

E-mailikonomikafebi@gmail.com 
priority because the management of zakat money as well as the wealth of Islamic individuals also includes the type of modern wealth of exploitation assets, income, wealth of financial securities and the wealth of Islamic financial institutions that benefit justice according to the command of Allah SWT (Berkman \& Macintyre, 1997; Rahman, 2015; Aziz et al., 2013). Therefore, income intended for payment of zakat must be obtained using halal (Mulawarman, Triyuwono, \& Ludigdo, 2007). The current method should be conducted according to the modern times by using information technology and be implemented related institutions.

Discussions on zakat payments and how to improve them have been done (Fuadah Johari $\&$ Mohd Ali, 20I5). Some researchers have adopted the study of motivational theories from the west. Just like that (Khamis et al., 20I4) which states that religious practices affect Muslims to comply with the payment of zakat. Besides religious factors, self- satisfaction and institutional factors also influence muzakki in paying zakat (Muda, Marzuki, \& Shaharuddin, 2006). One factor of trust in the institution is the ease of tax deduction for zakat issued (M. A. A. Aziz \& Abdullah, 2013), personal financial planning affects the motivation of muzakki in paying zakat. Next Doktoralina \& Bahari, (2017) states that if the ability to accommodate the needs of hajiyyat and tahsiniyyat increases, the level of intention to pay zakat will also increase. Basically, muzakki pays zakat because of spiritual value, economic value, humanistic value, and moral/psychological value (Bachmid, Salim, Armanu, \& Djumahir, 2012).

Besides, some studies discuss muzakki's behaviour in paying zakat by using reasoned action theory and the theory planned behavioural by Ajzen (199I). For example the study of Al, Saad, Haniffa, Al, \& Saad, (20I4); Maisarah Syazwani Othman, (20II); Ram A. Jaffri Saad, Bidin, Idris, \& Md Hairi Md Hussain, (20I0); Zunaidah, Othman Azhana \& Rafien, (20II) which conducts religious compliance studies in payment of zakat. Next Mustafa Murtala Oladimeji Abioye, Muslim Har Sani Mohamad, \& Muhammad Akhyar Adnan, (20II) states that adherence to zakat rules will also influence the enhancement of zakat collection. Similarly, with the intention to pay the zakat done by Raedah Sapingi, Noormala Ahmad, \& Marziana Mohamad, (201I). It states that attitudes, subjective norms and behavioural control can affect the compliance of individual intentions in paying zakat.

Regarding the distribution of zakat money, Imam al-Ghazali and al-Syatibi that bring good benefits to life for every human being must fulfil two things namely dharuriyyat (basic needs) and hajiyyat (comfort)(Abu Bakar \& Abdul Rashid, 20I0; Umar, 20I4). However, zakat money will be distributed to eight asnaf as stated in the Qur'an (Mayes, Setiawan, Isbah, \& Zuryani, 20I7; Nur Barizah Bakar \& Abd.Ghani, 20II) still have a challenge. Some of these challenges are lack of coordination (Jahar, 20I0), there are still muzakki who come directly to pay zakat at the zakat institution or give it directly to help to mustahiqq, and there are some who pay through banks, but it is not well integrated (M. A. A. Aziz \& Abdullah, 20I3). As the study findings Badan Amil Zakat Nasional (20I7) states that Zakat collection is still low that is I.3\% of the expected potential.

In the past, the Government had an obligation to manage and distribute zakat (Indonesia Magnificence of Zakat, 2010). However, at this time, the mindset must be changed as a statement (Salleh, 2018) namely the mobilisation of Islamic economics (one in zakat control) needs to be built with the intention of mardlatillah (the blessings of Allah SWT). Some studies also do not categorically state that the income earned in Islamic law is in a halal manner 
(Mulawarman et al., 2007). This proves that some strategies and missions are that are incompatible with zakat institutions or because of the complicated bureaucracy, as well as growth in productive activities is not achieved.

Furthermore, Regarding Mobilisation and culture of mutual assistance in paying zakat. The culture of mutual assistance in Islam is highly recommended as stated in the Quran in surah al-Ma'idah ( $5: 2 \& 5: 54)$. Ibn Katsir explains that they never retire from principle, obedient to Allah SWT, uphold His limits, fight against His enemies and do Amar ma'ruf and Nahi mungkar. They have never dropped from it. Nothing can stop them and never fear reproach and criticism. When turned, then Allah SWT spoke in Surah Muhammad (47:38), an-Nisa (4:33), and Ibrahim (I4: 19-20) with a firm warning that would replace with other people. This is in line with the statement of Muhammad Syukri Salleh (2018) which states that building the mobilisation of Islamic economics can follow the changing times while still aiming at the concept of obtaining the benefits of Allah SWT (mardlatillah).

As many as I22 million Indonesians are actively involved in using technology equipment as a convenience (Ministry of Communication and Informatics, 20I7). This is an essential role in mobilising people in the direction of paying zakat (Abdullah \& Suhaib, 20II). As the cultural dimensions conveyed by Hofstede \& Bond, (1984) that individuals think about the long-term consequences that will occur if they do something or are known by long-term orientation (LTO). Especially in Islamic and Muslim countries, the zakat sector gets additional strength based on norms (local culture) and religious obligations (Khan, 2007). Therefore, (Doktoralina \& Bahari, 2018) suggests mobilisation to pay zakat according to science/technology change (Subianto, 2013; Sudarwati \& Sayekti, 20II) and new things continue to emerge along with the progress of science/technology. Besides, this is one of the zakat potential exploration proposals and provides the facilitation of ease in introducing and educating people concering the laws and policies of zakat, zakat property and zakat calculation procedures (Chalikuzhi, 2009; Hafidhuddin, 20I I).

Changes occur according to the Islamic laws. Although this method will exchange information technology, its distribution is considered appropriate through decentralisation (Rosadi \& Athoillah, 2016; Kassim, 2016; Lessy, 2013). This will give the impression of transparency to muzakki, mustahiqq and the public. It can also add value to muzakki's confidence in paying zakat, and the government supports the mobilisation of zakat payments through the regulation with the aim of zakat institutions and government agencies to achieve the goals (Halimatusa'diyah, 20I5). As a description Study Differentiation Aspects, the gap analysis of the conceptual study is shown Previous research discuss about Traditional and Local Computerization, Zakat management centralised and decentralised, centralised collection and distribution, and AHP Approach (Analytical Hierarchies Process) and The Analysis done discuss Integrated/using the latest technology, Collection. The concept of the current study is the distribution management is centralised with centralised reporting system connectivity, and The culture of mutual assistance approach as a strength of Islamic process

\section{METHODOLOGY}

This study uses the documentation analysis method as a social research method (Bowen, 2009)

https://ejournal.radenintan.ac.id/index.php/ikonomika

E-mailikonomikafebi@gmail.com 


\section{RESULTS AND DISCUSSION}

Sharing religious values because strategic thinking does not always produce cooperation (Latief, 2012). Hence, many discussions on muzakki and mustahiqq's motives and behaviours, management in zakat institutions, or on zakat potential are concerned. At this point, the bureaucracy and the lack of internal coordination between the government and the institution of zakat have not been optimal (Halimatusa'diyah, 2015). Real data of muzakki and mustahiqq should support it. Besides, zakat management should be able to adapt to managing good control and accounting (Rekarti \& Doktoralina, 2017). Therefore, (Huda et al., 20I4) provide solutions for the management of zakat in Indonesia with The Analytic Hierarchy Process (AHP) developed by Saaty, (2008), i.e., in public administration.

Although some communities are aware that zakat is a religious obligation (Tajuddin, Azman, \& Shamsuddin, 2015), in fact, zakat collection is still low. Therefore, the role of da'wah and reminding each other among fellow Muslims remains a highlight. The part of da'wah is essential because it corresponds to the Qur'an. The da'wah model undertaken by zakat institutions is to adjust the era/technological change by reducing the traditional role of such as sending amil to every home (Salleh, 2006).

Figure I

Conceptual framework

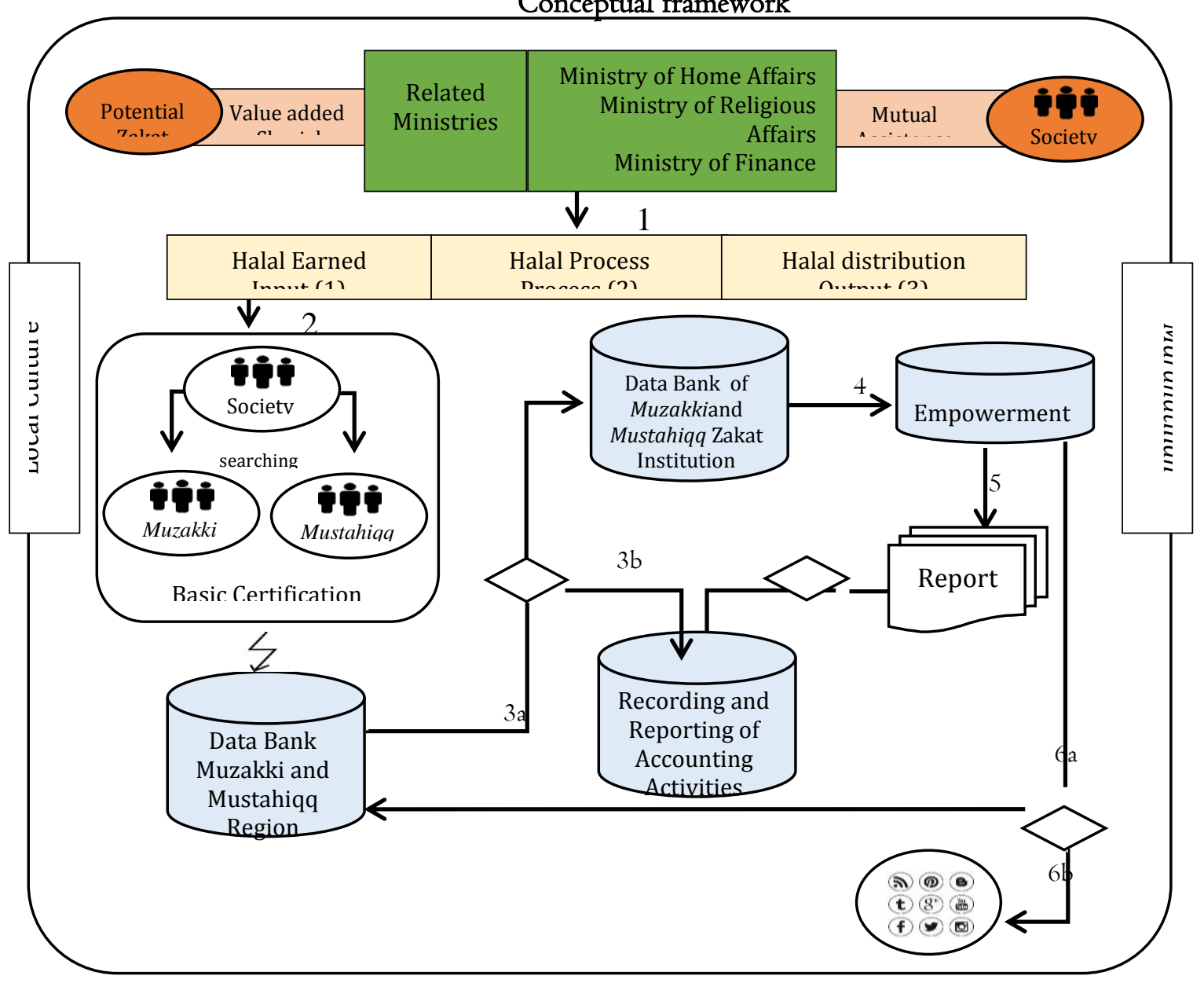


Muslims, technologists and the mutual assistance nature of the Indonesian people are a power of zakat productivity, while the changing of the information technology era is a necessity. However, information on the values of al-ruhiyyah tarbiyah is to cultivate the human rohaniyah side to be able to live this life easily and lightly. Also, proper technical digitalisation in delivering effective administrative management in the collection of zakat and distribution according to the Qur'an is to optimise the use of technology (Noorhayati, 20II). The reason is to build mobilisation of paying zakat with technology is expected to increase the acceptance of zakat in various areas in Indonesia extrinsically and intrinsically (Senthe, 2012; Muharman, Nurul Ibtisam, Yusoff, \& Abdurrahman, 201I).

The concept model in figure $I$ is a measure of mutual assistance in the technical activity of zakat payment mobilisation. Related institutions have a role in increasing the potential of zakat through the mobilisation of community cultural power and applying the Islamic concept. The first step, government institutions must understand the idea of the added value of sharia. The second step, the socialisation of the added benefit of sharia in zakat is socialised in Halal InputProcess-Output in every city/district/province. The community, muzakki and mustahiqg involved and recorded are given the official certification of zakat institutions by numbering and being used as data banks. The purpose is that only Amilin and the official board of zakat certified muzakki are allowed to pay zakat. The third step is the integrated district data bank of all its activities to the central zakat institution (3a). The aim is to obtain real data on the payment of zakat in government official zakat institutions. Integrated, muzakki data, mustahiqq are also recorded in accounting activities (3b). This becomes the validity of data and gives the community a role. In the empowerment program (fourth step), all events are returned to the district's mustahiqq data by keeping the poverty index in mind. Direct empowerment activities will be recorded in central institution reports (step five) and return to areas with national imbalances (step six) to be broadcast on social media in general.

Eventually, all program reports are returned to the public and other decision makers. This configuration also supports the study Salleh, (20I4)so that zakat management can be configured adequately by still referring to the source of Islam, not to the altered definition of eclectic-accommodating western ethnocentric concepts.

Community certifications related to zakat, muzakki and mustahiqq need to be realised by the government. The data presented by the government and zakat institutions should be appropriate. If this business goes smoothly, the whole 
poverty alleviation program will work. Zakat institutions and governments will get accurate data.

\section{E. CONCLUSION}

In general, the mobilisation of paying zakat is one of the alternatives to increase the amount of zakat collection. The government needs to support the mobilisation of zakat payments in Indonesia. One of the forms of support is to certify muzakki and mustahiqq. The goal is to avoid duplication of collection and distribution. It can also contribute to the study of discipline in the initially forced, coerced, be able, be accustomed and eventually become a culture in zakat payment practices that can be developed in accor\&ce to the local culture, so that all elements (muzakki, mustahiqq, zakat council, government, society). The government will obtain muzakki and mustahiqq data and all empowerment programs undertaken. Empirically, the concept of this model will be empirically tested on field study applications. Control of muzakki activity data related to consciousness, willingness to donate, confidence in collection and distribution by following the changing times is indispensable. Innovative businesses such as socialisation of mardhatillah (To getting Bless of God) concepts in zakat payment mobilisation need to be adapted to local culture. The contribution of this documentation study gives the impetus to the delivery of knowledge by utilizing the technology can be tested in most countries. Hence, the main objective of the scientific concept is to foster a country's practical framework that stimulates muzakki's discipline in paying zakat and comprehensive data collection of mustahiqq to promote zakat and institutions to develop an integrated and controlled zakat payment mobilisation model.

\section{Acknowledgement}

We wish to thank Profesor Dr M. Dailamy Saputro, Associate Profesor Dr H. Purwanto S.K., Dr. Azreen Hamiza Abdul Aziz and the External Reviewer. We also express our appreciation to the team of the economics and business faculty of the Universitas Mercu Buana, the Center for Islamic Development Management Studies (ISDEV) of Universiti Sains Malaysia and to all of the Ikatan Ahli Ekonomi Islam team of Indonesia Komisariat Universitas Mercu Buana, which have been very constructive in the various stages of the development of this article. 


\section{REFERENCES}

Abd.Ghani, A. H., \& Abu Bakar, M. H. (20II). Towards Achieving the Quality of Life in the Management of Zakat Distribution to the Rightful Recipients (The Poor and Needy). International Journal of Business and Social Science, 2(4), 237-246.

Abdullah, M., \& Suhaib, A. Q. (20II). The Impact of Zakat on Social Life of Muslim Society. Pakistan Journal of Islamic Research, 8, 85-9I.

Abu Bakar, N. B., \& Abdul Rahman, A. R. (2007). A Comparative Study of Zakah and Modern Taxation. J. KAU: Islamic Economics, 2O( I), 25-40.

Abu Bakar, N. B., \& Abdul Rashid, H. M. (2010). Motivations of Paying Zakat on Income: Evidence from Malaysia. International Journal of Economics and Finance, 2(3), 76-85.

Ajzen, I. (I99I). The Theory of Planned Behavior. Organizational Behavior and Human Decision Processes, 50, I79-2I I.

Al Haq, M. A., \& Abd. Wahab, N. (2017). Effective Zakat Distribution: Highlighting Few Issues and Gaps in Kedah, Malaysia. Al-Iqtishad: Journal of Islamic Economics, 9(2), 259-288.

Al Jaffri Saad, R., \& Haniffa, R. (20I4). Determinants of zakah ( Islamic tax ) compliance behavior. Journal of Islamic Accounting and Business Research, $5(2), 20 I 4$.

Andriani, S., \& Fathya, F. (20I3). Zakat Sebagai Pengurang Pajak Penghasilan pada Badan Amil Zakat. JRAK, 4(I), I3-32.

Arafah, W., \& Nugroho, L. (20I6). Maqhashid sharia in clean water financing business model at Islamic bank. International Journal of Business and Management Invention, 5(2), 22-32.

Aziz, A. A., Jamil, M. M., Ismail, H., \& Abdul Rahman, N. (2013). The Importance of Zakat Institution in Malaysia. The 5th International Conference on Financial Criminology (ICFC) 2013, I34-I44.

Aziz, M. A. A., \& Abdullah, M. H. (2013). The Comparison between Zakat (Islamic Concept of Taxation) and Income Tax: Perceptions of Academician in the State of Perak, Malaysia. International Conference on Business, Economics, and Accounting, (March), 8.

Bachmid, G., Salim, U., Armanu, \& Djumahir. (2012). Perilaku muzakki dalam membayar zakat mal (Studi fenomenologi pengalaman muzakki di Kota Kendari ). Jurnal Aplikasi Manajemen, IO(2), 425-436. 
Badan Amil Zakat Nasional. (2018). Outlook Zakat Indonesia 2018. Jakarta, Indonesia: Pusat Kajian Strategis Badan Amil Zakat Nasional (BAZNAS).

Beik, I. S. (20I5). Towards International Standardization of Zakat System. In Fiqh Zakat International Conference 2015 (pp. 3-I7).

Beik, I. S., \& Arsyianti, L. D. (2013). Optimization of Zakat Instrument in Indonesia's Poverty Alleviation Programme. In 'Poverty Alleviation and Islamic Economics and Finance: Current Issues and Future Prospect' (pp. I19).

Berkman, L. F., \& Macintyre, S. (I997). The measurement of social class in health studies: old measures and new formulations. IARC Scientific Publications, (I38), 5I-64.

Bidin, Z., Idris, K. M., Shamsudin, M., \& Faridahwati. (2009). Predicting Compliance Intention on Zakah on Employ- ment Income in Malaysia: An Application of Reasoned Action Theory. Jurnal Pengurusan, 28, 85-I02.

Bowen, G. A. (2009). Document Analysis as a Qualitative Research Method. Qualitative Research Journal, $9(2), \quad 27-40$. http://doi.org/I0.33I6/QRJ0902027

Bremer, J. (2013). Zakat and Economic Justice: Emerging International Models and their Relevance for Egypt. In Third Annual Conference on Arab Philantrophy and Civic Engagement (pp. 5I-74).

Chalikuzhi, A. (2009). Problems and prospects of contemporary zakat management: A qualitative embedded case studies investigation. Unpublished Dissertation.

Desilver, D., \& Masci, D. (2017). World's Muslim population more widespread than you might think. Retrieved from http://www.pewresearch.org

Doktoralina, C. M. (2016a). Potential Income Zakat Revenue In Private Universities: Conceptual Framework Analysis. In WAPI 9 (Vol. I I, p. I0).

Doktoralina, C. M. (2016b). Relationship Between Extrinsic Motivation And Compliance To Pay Income Zakat Among Academic People In Indonesia: Conceptual Framework Analysis. In Workshop Antarbangsa Pembangunan Berteraskan Islam (Vol. 9, pp. I0-I6).

Doktoralina, C. M. (2017). Niat Membayar Zakat Pendapatan Dalam Kalangan Ahli Akademik. In The I2th ISDEV International Graduate Workshop (INGRAW) (Vol. I2, pp. I-I2).

Doktoralina, C. M., \& Bahari, Z. (2017). The Relationship between Income Household and Intention to Pay Zakat on Income among Indonesian 
Academicians. Mediterranean Journal of Social Sciences, 8(4), 27-39.

Doktoralina, C. M., \& Bahari, Z. (2018). Zakat Accounting Information System in Private Higher Education.

Hafidhuddin, D. (20II). Peran Strategis Organisasi Zakat Dalam Menguatkan Zakat Di Dunia (The Strategic Role of Zakat Organization in Strengthening Zakah in the World). Jurnal Ekonomi Islam Al-Infaq, 2(I), I-4.

Halimatusa'diyah, I. (2015). Zakat and Social Protection: The Relationship Between Socio-religious CSOs and the Government in Indonesia. Journal of Civil Society, II(I), 79-99.

Hassan, M. K., \& Ashraf, A. (2010). An integrated Poverty Alleviation Model Combining Zakat. Awqaf and Micro.

Hati, S. R. H., \& Idris, A. (20I4). Antecedents of customers' intention to support Islamic social enterprises in Indonesia. Asia Pacific Journal of Marketing and Logistics, 26(5), 707-737.

Haughton, J., \& Khandker, S. R. (2009). Handbook on povertyt inequality. World Bank Publications.

Hj. Abdul Majid, M. Z. (2003). Pengurusan Zakat (Management of Zakat). Kuala Lumpur: Dewan Bahasa dan Pustaka, 2003. (Cet. I.). Kuala Lumpur: Dewan Bahasa dan Pustaka,.

Hofstede, G., \& Bond, M. H. (1984). Hofstede's culture dimensions: An independent validation using Rokeach's value survey. Journal of CrossCultural Psychology, I5(4), 4I7-433.

Huda, N., Anggraini, D., Muhamad Ali, K., Rini, N., \& Mardoni, Y. (20I4). Solutions to Indonesian Zakah Problems Analytic Hierarchy Process Aprroach. Journal of Islamic Economics, Banking and Finance, IO(3).

Hussain, A., \& Abdullah. (2015). Importance of ZAKAT in the Establishment of the Society. Global Journal for Research Analysis, 4(4), I-2.

Indonesia Magnificence of Zakat. (2010). Mengawal Zakat di Parlemen.

Jahar, A. S. (2010). Masa Depan Filantropi Islam Indonesia: Kajian Lembagalembaga Zakat dan Wakaf. In Annual Conference on Islamic Studies (ACIS) ke IO di Banjarmasin, I-4 November, Kalimantan Selatan.

Johari, F., Ali, A. F. M., \& Aziz, M. R. A. (2015). A Review of Literatures on Current Zakat Issues: An Analysis between 2003 - 2013. International Review of Research in Emerging Markets and the Global Economy (IRREM), $I(2), 336-363$.

Johari, F., Mohd Ali, A. F., Aziz, M. R. A., \& Ahmad, N. (20I4). The importance 
of zakat distribution and urban-rural poverty incidence among Muallaf (new convert). Asian Social Science, IO(2I), 42-53.

Kahf, M. (I999). The Principle of Socio-economic Justice in the Contemporary Fiqh of Zakah. IQTISAD Journal of Islamic Economics, I(I), 24-44.

Kahf, M. (2008). Role of Zakah and Awqaf in Reducing Poverty: A Proposed Institutional Setting within the Spirit of Shari'ah. Thoughts on Economics, I8(3), 40-67.

Kasri, R. A. (2013). Giving behaviors in Indonesia: motives and marketing implications for Islamic charities. Journal of Islamic Marketing, 4(3), 306324.

Kassim, P. W. S. (2016). Issues and challenges in financing the poor: case of Baitul Maal Wa Tamwil in Indonesia. International Journal of Bank Marketing, 34(2), 2I6-234.

Khamis, M. R., Mohd, R., Md Salleh, A., \& Nawi, A. S. (20I4). Do religious practices influence compliance behaviour of business Zakat among SMEs? Journal of Emerging Economies and Islamic Research, 2(2), I-I6.

Khan, M. F. (2007). Integrating Faith-Based Institutions (Zakah and Awqaf) in Poverty Reductions Strategies (PRS). In Islamic Research and Training Instiute (IRTI), 3I. (pp. I-3I).

Khandker, S. R., Koolwal, G. B., \& Samad, H. A. (2009). Handbook on impact evaluation: quantitative methods and practices. World Bank Publications.

Latief, H. (2012). Islamic Charities and Social Activism: Welfare, Dakwah and Politics in Indonesia.

Lessy, Z. (2009). Zakat (Alms-Giving) Management In Indonesia: Whose Job Should It Be ? La_Riba Jurnal Ekonomi Islam, III(I), I06-I I9.

Lessy, Z. (2013). Philanthropic zakat for empowering Indonesia's poor: A qualitative study of recipient experiences at Rumah Zakat. ProQuest Dissertations and Theses.

Mayes, A., Setiawan, D., Isbah, U., \& Zuryani, H. (2017). The Role of Productive Zakat for Helping Poor Community in Rokan Hulu Regency (Case Study of National Amil Zakat of Rokan Hulu Regency). International Journal of Finance and Accounting, 6(6), I79-I85.

Ministry of Communication and Informatics. (2017). Internet User Indonesia Number Six of the World (Pengguna Internet Indonesia Nomor Enam Dunia). Retrieved from https://kominfo.go.id

Ministry of Religious Affairs of the Republic of Indonesia. (2018). Isu Pokok 
Pembahasan Munas Forum Zakat. Retrieved from https://kemenag.go.id Mohd Noor, M. A., Wahid, H., \& Nor Ghani Md., N. (2004). Kesedaran Membayar Zakat Pendapatan Di Kalangan Kakitangan Profesional Universiti Kebangsaan Malaysia. Islamiyyat, 26(2), 59-67.

Muda, M., Marzuki, A., \& Shaharuddin, A. (2006). Factors influencing individual participation in zakat contribution: Exploratory investigation. In Seminar for Islamic Banking and Finance 2006 (iBAF2006) (pp. I-I0).

Muharman, L., Ibtisam, Y. N., Yusoff, O., \& Abdurrahman, A. D. (20II). Enhancement of Zakat Distribution Management System: Case Study in Malaysia. International Management Conference 201 I Proceedings.

Mulawarman, A. D. (2009). Eksistensi Laporan Nilai Tambah Syariah Berbasis Rezeki. Jurnal Riset Akuntansi Indonesia, I2(2), I03-I20.

Mulawarman, A. D., Triyuwono, I., \& Ludigdo, U. (2007). Rekonstruksi Teknologi Integralistik Akuntansi Syariah: Sharfate Value Added Statement. Jurnal Akuntansi Dan Keuangan Indonesia, 4(I), I-24.

Muliyaningsih, H. D. (2013). Social Entrepreneurship in Islamic Social Welfare System. In International Proceedings of Economics Development and Research (pp. 44-49).

Mustafa Murtala Oladimeji Abioye, Muslim Har Sani Mohamad, \& Muhammad Akhyar Adnan. (20II). Antecedents of Zakat payers' trust: The case of Nigeria. International Journal of Economics, Management \& Accounting, 3(I9), I33-I64.

Nastiti, A. S., \& Wardayati, S. M. (2015). Implementation of Shariah Accounting Theory in Shariah Value Added: A Theoretical Study. Global Journal of Business and Social Science Review, 4(I), 9-I5.

Noorhayati, A. H. (20II). Customers' Perception of Online Zakat Payment Between Government and Private Sector Employees. Universiti Utara Malaysia.

Nugroho, L., \& Husnadi, T. C. (2017). Maslahah and Strategy to Establish a Single State-Owned Islamic Bank in Indonesia. Tazkia Islamic Finance and Business Review, IO(I).

Osili, U., \& Ökten, Ç. (2016). Giving in Indonesia: A Culture of Philanthropy Rooted in Islamic Tradition. In The Palgrave Handbook of Global Philanthropy.

Othman, M. S. (20II). Zakat compliance intention behavior on employment income among state government servants in Kelantan. Universiti Utara 
Malaysia, Malaysia. Retrieved from http:/ / etd.uum.edu.my

Powell, R. (2009). Zakat: Drawing insights for legal theory and economic policy from Islamic jurisprudence. Pitt. Tax Rev., 7, 43.

Rahman, T. (20I5). Akuntansi Zakat, Infaq dan Sedekah (PSAK I09): Upaya Peningkatan Transparansi dan Akuntabilitas Organisasi Pengelola Zakat (OPZ). Muqtasid: Jurnal Ekonomi Dan Perbankan Syariah, 6 I), I4I-I64.

Raquib, A. (20II). Islamic Banking \& Zakat- An Alternative Approach to Poverty Reduction in Bangladesh. Journal of Islamic Economics, Banking and Finance, $7(2), \mathrm{I} I-26$.

Rekarti, E., \& Doktoralina, C. M. (2017). Improving Business Performance: A Proposed Model for SMEs. European Research Studies Journal, 20(3), 6I3623.

Rosadi, A., \& Athoillah, M. A. (2016). Distribusi zakat di Indonesia: antara sentralisasi dan desentralisasi. IJTIHAD Jurnal Wacana Hukum Islam Dan Kemanusiaan, I5(2), 237.

Saad, R. A. J., Bidin, Z., Idris, K. M., \& Md Hussain, M. H. (20I0). Faktor-faktor yang mempengaruhi Gelagat Kepatuhan Zakat Perniagaan. Jurnal Pengurusan, 30, 49-6I.

Saaty, T. L. (2008). Decision making with the analytic hierarchy process. International Journal of Services Sciences, I(I), 83.

Salleh, M. S. (2006). Lokalisasi Pengagihan Zakat: Satu Cadangan Teoretis, dalam Zakat: Pensyariatan, Perekonomian \& Perundangan. Zakat: Pensyariatan, Perekonomian \& Perundangan. Bangi: Penerbit Universiti Kebangsaan Malaysia.

Salleh, M. S. (20I4). Organizational and Definitional Reconfiguration of Zakat Management. International Journal of Education Research, 2(5), 6I-70.

Salleh, M. S. (2018). Ada yang keliru dari ekonomi Islam sekarang (something is wrong with the current Islamic economy). Retrieved March 27, 20I8, from http://nusantarakini.com

Sapingi, R., Ahmad, N., \& Mohamad, M. (20II). A study on zakah of employment income: Factors that influence academics' intention to pay zakah. In 2nd International Conference On Business and Economic Research (pp. 2492-2507).

Sari, M. D., Bahari, Z., \& Hamat, Z. (2013). Review on Indonesian Zakah Management and Obstacles. Social Sciences, 2(2), 76-89.

Senthe, S. E. (2012). Transformative Technology in Microfinance: Delivering Hope Electronically. Pittsburgh Journal of Technology Law and Policy, 
I3( I), 63.

Siswantoro, D., \& Nurhayati, S. (2012). Factors Affecting Concern about Zakat as a Tax Deduction in Indonesia. Int. J. Manag. Bus. Res, 2(4), 293-3I2.

Subianto, A. (2013). Mengoptimalkan Potensi Zakat Dengan Sistem (Optimizing Zakah Potential With System). BAZNAS, I0-I I.

Sudarwati, Y., \& Sayekti, N. W. (20II). Konsep Sentralisasi Sistem Pengelolaan Zakat Dalam Pemberdayaan Ekonomi Umat. Jurnal Ekonomi \& Kebijakan Publik, 2(I), 559-584.

Suryanto, T. (2014). Determinants of Audit Fee Based on Client Attribute, Auditor Attribute, and Engagement Attribute to Control Risks and Prevent Fraud: A Study on Public Accounting Firms in Sumatra-Indonesia. International Journal in Economics and Business Administration, 2(3), 27-39. Syahrullah, \& Ulfah, M. (2016). Response of Indonesian Academicians Toward Factors Influencing the Payment of Zakat on Employment Income. Research on Humanities and Social Sciences ISSN, 6(I0), 87-94.

Tajuddin, T. S., Azman, A. S., \& Shamsuddin, N. (20I5). Compliance Behaviour Of Zakat on Salary Income Among Muslim, 20I5(June), 656-664.

Umar, N. (20I4, May 3). Manajemen Qalbu: Keperluan Tahsiniyat. Pusat Informasi Dan Hubungan Masyarakat, p. II. Indonesia.

Waddell, S. (2000). New institutions for the practice of corporate citizenship: Historical, intersectoral, and developmental perspectives. Business \& Society Review (00453609), I05(I), I07.

Wahid, H., Ahmad, S., \& Kader, R. A. (2009). Pengagihan zakat oleh institusi zakat kepada lapan asnaf: Kajian di Malaysia. In Seminar Kebangsaan Ekonomi Islam 2008/09 pada IO-II Februari 2009 di APIUM(pp. I-I7).

Wibisono, Y. (2015). Mengelola Zakat Indonesia. Kencana.

Yunianto, D., Nariyono, B., Daryanto, B., Oetomo, E., Maksudi, E. I., \& Hairudin, E. (2017). Bidang Studi Geopolitik dan Wawasan Nusantara (2, Lemhann ed.). Jakarta, Indonesia: Lembaga Ketahanan Nasional Republik Indonesia.

Yusuf Al Qardawi. (20I I). Hukum zakat. Jakarta (ID): Lentera Antar Nusa.

Zunaidah, O. A., \& Rafien, N. S. M. (201I). Relationship on Economic and Attitude Factors towards Evasion on Zakat of Income: A Study Among Public Servants in Melaka. UiTm Melaka. 
Mobilisation of Income Zakat Payment In Indonesia

Caturida Meiwanto Doktoralina ${ }^{1}$, Zakaria Bahari ${ }^{2}$, Sakinatul Raadiyah Abdullah ${ }^{3}$ 